Ciencias Marinas (2000), 26(2): 355-367

http://dx.doi.org/10.7773/cm.v26i2.575

\title{
MICROAEROPHILIC BACTERIAL BIOMASS MEASUREMENTS BASED ON ADENOSINE TRIPHOSPHATE AND DIRECT COUNTING TECHNIQUES IN A SEMI-SOLID AGAR COLUMN
}

\section{BIOMASA BACTERIANA MICROAEROFÍLICA CALCULADA POR LAS TÉCNICAS DE ADENOSINA TRIFOSFATO Y DE CONTEO DIRECTO EN UNA COLUMNA DE AGAR SEMISÓLIDO}

\author{
María de Jesús Ferrara-Guerrero ${ }^{1}$ \\ Armand Bianchi ${ }^{2}$ \\ ${ }^{1}$ Departamento El Hombre y su Ambiente \\ Universidad Autónoma Metropolitana, Unidad Xochimilco \\ Calzada del Hueso 1100, Col. Villa Quietud \\ 04960 México DF, México \\ E-mail: fgmd6735@cueyatl.uam.mx \\ ${ }^{2}$ Laboratoire de Microbiologie Marine ER 223 CNRS, \\ Campus Luminy, Case 907 \\ Marseille, France \\ Recibido en marzo de 1999; aceptado en marzo de 2000
}

\begin{abstract}
Microaerophilic-diazotrophic bacterial biomass was measured by Adenosine Triphosphate (ATP) extraction and direct counting/biovolume techniques. Microaerophilic bacterial growth in a semi-solid agar column is visible in the form of sharp, well-defined growth rings at different depths within the column according to oxygen requirements. The microaerophilic zone is found between 3 and $15 \mathrm{~mm}$ below the agar surface, where the dissolved oxygen concentration varies from 4 to $172 \mu \mathrm{M}$. Biomass measurements calculated using a conventional conversion factor C/ATP of 250 were around ten times lower than those calculated according to the direct counting/biovolume technique. In the present study, we propose a conversion factor of $356 \mu \mathrm{g} \mathrm{C} / \mathrm{mL}$ ATP that gives biomass measurements nearer to those obtained by direct counting. The highest bacterial metabolic activity was found between 5 and $10 \mathrm{~mm}$ depth $\left(0.15 \pm 0.029 \mu \mathrm{g}\right.$ ATP $\left.\mathrm{mL}^{-1}\right)$, coinciding with optimum oxygen concentration levels for microaerophilic growth $(6.5$ to $114 \mu \mathrm{M})$.
\end{abstract}

Key words: microaerophilic bacteria, biomass, ATP, direct counting.

\section{RESUMEN}

La biomasa bacteriana microaerofílica-diazotrofa fue evaluada por las técnicas de extracción de Adenosina Trifosfato (ATP) y de conteo directo/biovolumen. El crecimiento bacteriano microaerofílico 
Ciencias Marinas, Vol. 26, No. 2, 2000

en columnas de agar semisólido se manifiesta en forma de anillos de crecimiento bien delimitados que se revelan a diferentes profundidades de la columna según sus necesidades de oxígeno. La zona microaerofílica se encuentra comprendida entre 3 y $15 \mathrm{~mm}$ por debajo de la superficie del agar, donde la concentración de oxígeno disuelto fluctúa entre 4 y $172 \mu \mathrm{M}$. Los valores de biomasa calculados utilizando un factor de conversión C/ATP convencional de 250 fueron aproximadamente diez veces menores que los calculados por el método de conteo directo/biovolumen. Durante esta investigación, se calculó un coeficiente de conversión de $356 \mu \mathrm{g} \mathrm{C} / \mathrm{mL}$ ATP que dio valores de biomasa más cercanos a los obtenidos por conteo directo. La mayor actividad metabólica bacteriana se encontró entre 5 y $10 \mathrm{~mm}$ de profundidad $\left(0.15 \pm 0.029 \mu \mathrm{g}\right.$ ATP $\left.\mathrm{mL}^{-1}\right)$, coincidiendo con la zona con concentraciones óptimas de oxígeno para el crecimiento microaerofílico $(6.5$ a $14 \mu \mathrm{M})$.

Palabras clave: bacterias microaerofílicas, biomasa, ATP, conteo directo.

\section{INTRODUCTION}

Bacterial biomass is regarded as one of the most important ecological parameters for evaluating the productivity of aquatic environments. Microbial ecosystems with aerobic and anaerobic zones are found in sediments (Jones, 1982; Revsbech and Jørgensen, 1986; Anderson and Helder, 1987; Ferrara-Guerrero and Bianchi, 1990), soils (Smith and Arah, 1986; Reddy et al., 1989; Skopp et al., 1990; Focht, 1992), stratified water columns (Karl, 1982; Jones, 1987; McDonough et al., 1986; Millero and Sohn, 1992; Wynn-Williams, 1992) and microbial biofilms (Nielsen et al., 1990). Strict aerobes depend upon molecular oxygen for their metabolism and strict anaerobes can only grow in an oxygen-free environment, whereas microaerophiles depend on molecular oxygen but in concentrations from $0.2 \%$ to $12 \%$ (Bowdre et al., 1976).

Analysis of microbial ecosystems in situ, in combination with studies on microbial cultures in the laboratory have provided detailed information on the functioning of microorganisms under both fully oxic and anoxic conditions. However, knowledge of the ecology and physiology of microorganisms in low-oxygen environments is still scarce.

The concentration of bacteria is usually quantified in liquid culture by spectrophotometric methods. These techniques are difficult

\section{INTRODUCCIÓN}

La biomasa bacteriana es considerada como uno de los parámetros ecológicos más importantes para evaluar la productividad de los ambientes acuáticos. Los ecosistemas microbianos con zonas aerobias y anaerobias se encuentran en sedimentos (Jones, 1982; Revsbech y Jørgensen, 1986; Anderson y Helder, 1987; Ferrara-Guerrero y Bianchi, 1990), suelos (Smith y Arah, 1986; Reddy et al., 1989; Skopp et al., 1990; Focht, 1992), columnas de agua estratificadas (Karl, 1982; Jones, 1987; McDonough et al., 1986; Millero y Sohn, 1992; Wynn-Williams, 1992) y tapetes microbianos (Nielsen et al., 1990). Los aerobios estrictos dependen del oxígeno molecular para su metabolismo y los anaerobios estrictos crecen únicamente en ambientes libres de oxígeno, mientras que los microaerofílicos dependen del oxígeno molecular pero en concentraciones de $0.2 \%$ a $12 \%$ (Bowdre et al., 1976).

Los análisis in situ de ecosistemas microbianos, junto con estudios realizados en el laboratorio con cultivos microbianos, han dado una información detallada sobre el funcionamiento de los microorganismos en condiciones aerobias y anaerobias. Sin embargo, el conocimiento de la ecología y fisiología de los microorganismos en ambientes con bajas concentraciones de oxígeno es muy escaso. 
to apply in a shake agar culture where the oxygen-sensitive bacteria form sharply defined growth layers at different agar column levels according to their oxygen requirements, since it is necessary to modify the gel scanning spectrophotometer so that it may be used with test tubes (Wimpenny et al., 1983; MacFarlane et al., 1984; Wimpenny and Waters, 1984; Kikuchi and Suzuki, 1986).

Other methods of determining the bacterial biomass are direct microscopy count and measurement of the concentration of Adenosine Triphosphate (ATP). Measurement of ATP concentrations in living cells is an indirect technique to determine viable bacterial biomass (Holm-Hansen and Booth, 1966; Hamilton and Holm-Hansen, 1967; Holm-Hansen, 1970; Daumas, 1973, 1989; Karl, 1980). This enables the measurement of the effect of different factors, such as oxygen concentration, nutrient limitation and culture conditions, on the microaerophilic metabolic activity.

In order to estimate the preferred oxygen concentration for microaerophilic growth in a semi-solid agar column, we quantified the bacterial biomass from ATP concentration in different microaerophilic growth levels. As a comparison, we calculated the bacterial biomass using the direct counting technique by epifluorescence as described by Hobbie et al. (1977), as well as by cellular volume measurements (van Wambeke, 1988; Torréton et al., 1989).

\section{MATERIAL AND METHODS}

Marine chemioorganotrophic microaerophilic bacteria from sandy-clay lagoon sediments have previously been revealed by us in a semi-solid growth culture medium containing low concentrations of organic substrates, and distributed in deep test tubes to obtain an oxygen gradient from the agar surface toward the
La intensidad de crecimiento bacteriano generalment se cuantifica en medios de cultivo líquidos utilizando métodos espectrofotométricos. Estas técnicas son difícilmente aplicables en un sistema de agar agitado, donde las bacterias sensibles al oxígeno forman películas de crecimiento finas y bien definidas a diferentes niveles de la columna de agar de acuerdo con sus requerimientos de oxígeno, ya que es necesario utilizar un espectrofotómetro con barrido de geles modificado para que pueda ser utilizado con tubos de prueba (Wimpenny et al., 1983; MacFarlane et al., 1984; Wimpenny y Waters, 1984; Kikuchi y Suzuki, 1986).

Otros métodos para la cuantificación de la biomasa bacteriana son el conteo directo por microscopía y la medida de la concentración deAdenosina Trifosfato (ATP). La estimación de las concentraciones de ATP, presente en todas las células vivas, proporciona un medio indirecto de evaluación de la biomasa bacteriana viva (Holm-Hansen y Booth, 1966; Hamilton y Holm-Hansen, 1967; HolmHansen, 1970; Daumas, 1973, 1989; Karl, 1980), lo que permite apreciar los efectos de diferentes factores, como la concentración de oxígeno, limitación en nutrimentos y condiciones de cultivo, sobre la actividad metabólica microaerofílica.

Por tanto, con el fin de medir la preferencia por una determinada concentración de oxígeno para el crecimiento microaerofílico dentro de una columna de agar agitado, se cuantificó la biomasa bacteriana a partir de la concentración de ATP existente en cada uno de los niveles de crecimiento microaerofílico. De manera comparativa, la biomasa bacteriana también fue calculada utilizando la técnica de conteo directo por epifluorescencia según Hobbie et al. (1977), junto con la determinación del volumen celular (van Wambeke, 1988; Torréton et al., 1989). 
Ciencias Marinas, Vol. 26, No. 2, 2000

deeper levels in the tube (Ferrara-Guerrero and Bianchi, 1990). As a result, the bacterial growth appears in the form of well-defined layers at different depths in the agar column, according to their oxygen requirements. After oxygen measurements in the layer with a Chemical Transidyne 1201 microsensor equipped with an oxygen needle electrode (0.07 o.d., $2.5 \mathrm{~cm}$ long, Diamond Electro-Tech Inc.), only those formed between 3 and $15 \mathrm{~mm}$ below the agar surface were under the microaerophilic zone (Ferrara-Guerrero and Bianchi, 1989; Ferrara-Guerrero et al., 1993).

The measurements of ATP concentration in each microaerophilic growth layer were carried out in duplicate, according to the method described by Holm-Hansen and Booth (1966) and Laborde (1972).

ATP extractions were carried out after seven days incubation in mineral medium containing $2 \mathrm{~g} \mathrm{~L}^{-1}$ of bacteriologic agar and $0.5 \mathrm{~g} \mathrm{~L} \mathrm{~L}^{-1}$ of calcium succinate (FerraraGuerrero and Bianchi, 1989; Ferrara-Guerrero et al., 1993); $1 \mathrm{~mL}$ was taken from the layer with a syringe and a spinal hypodermic needle, and resuspended in $4 \mathrm{~mL}$ of a buffer Tris $\mathrm{pH} 7$. The mix was centrifuged for 15 minutes at $2300 \times \mathrm{g}$ to eliminate residual agar. ATP measurements were carried out with the luciferineluciferase technique, using a luminometer 1250 LKB (Daumas, 1973; Burninson, 1975; Cavari, 1976).

In order to calculate the microaerophilic organic carbon, and owing to the fact that there is very little information about microaerophilic bacterial biomass measurements in culture media, the ATP concentration was converted to cellular carbon using a conversion factor (C/ATP) of $250 \mu \mathrm{g} \mathrm{C} / \mu \mathrm{g}$ ATP (HolmHansen, 1969; Karl, 1980; Romano, 1982), calculated from aerobic and anaerobic phytoplankton and bacterioplankton cultures, and a factor of $356 \mu \mathrm{g} \mathrm{C} / \mu \mathrm{g}$ ATP, calculated during this investigation.

\section{MATERIAL Y MÉTODOS}

Bacterias marinas quimioorganotrofas microaerofílicas provenientes de sedimentos lagunares areno-arcillosos han sido evidenciadas anteriormente, en un medio de cultivo conteniendo bajas concentraciones de agar y de sustratos orgánicos, y repartido en tubos de prueba profundos a fin de obtener una columna de agar semisólido que permita el establecimiento de un gradiente de oxígeno de la superficie del agar hacia las zonas más profundas del tubo (Ferrara-Guerrero y Bianchi, 1990). Como resultado, el crecimiento bacteriano aparece como una delgada película bien definida a diferentes profundidades de la columna de agar, según sus necesidades de oxígeno. Después de medir el oxígeno en la película con un microsensor Chemical Transidyne 1201 equipado con un electrodo de oxígeno dentro de una aguja hipodérmica (0.07 o.d., $2.5 \mathrm{~cm}$ de longitud, Diamond Electro-Tech Inc.), únicamente aquellas que se formaron entre $3 \mathrm{y}$ $15 \mathrm{~mm}$ por debajo de la superficie de agar fueron consideradas dentro de la zona microaerofílica (Ferrara-Guerrero y Bianchi, 1989; Ferrara-Guerrero et al., 1993).

La concentración de ATP a nivel de la película de crecimiento microaerofílico fue medida por duplicado, según el método descrito por Holm-Hansen y Booth (1966) y Laborde (1972).

Las extracciones de ATP fueron efectuadas después de siete días de incubación en un medio mineral conteniendo $2 \mathrm{~g} \mathrm{~L}^{-1}$ de agar bacteriológico y $0.5 \mathrm{~g} \mathrm{~L}^{-1}$ de succinato de calcio (Ferrara-Guerrero y Bianchi, 1989; FerraraGuerrero et al., 1993). Una alícuota de $1 \mathrm{~mL}$ fue tomada con una jeringa y una aguja hipodérmica tipo espinal y resuspendida en $4 \mathrm{~mL}$ de una solución amortiguadora Tris $\mathrm{pH}$ 7. Con el fin de eliminar los residuos de agar presentes en el medio de cultivo, la mezcla fue centrifugada a $2300 \times \mathrm{g}$ durante 15 minutos. Las 
Ferrara-Guerrero and Bianchi: Microaerophilic bacterial biomass measurements

Microaerophilic bacteria were enumerated by epifluorescence microscopy according to Hobbie et al. (1977) and Porter and Feig (1980). The greatest difficulty in the use of this technique lies in the dissociation of the bacterial aggregates and in the separation of the cells from the agar matrix which forms the culture medium.

In order to separate the cells from the agar matrix, $1 \mathrm{~mL}$ of the layer was resuspended in $9 \mathrm{~mL}$ of a $0.002 \mathrm{M} \mathrm{Na} \mathrm{Na}_{2} \mathrm{O}_{7}$ solution for 20 minutes and then sonicated for 60 seconds at $45 \mathrm{~W}$ (60\% efficiency) using an ultrasonic processor (Vibra Cell 600W, Bioblock Scientific) equipped with a $3-\mathrm{mm}$ probe; $250 \mu \mathrm{L}$ from this suspension were diluted in $10 \mathrm{~mL}$ of filtered sterilized seawater with a final concentration of $0.25 \%$ formaldehyde and $0.05 \%$ sodium azide (Reimars and Smith, 1986). Then, $2 \mathrm{~mL}$ from the supernatant liquid were colored for $10 \mathrm{~min}$ utes with DAPI (4',6-diamidine-2-phenilindol dihydrochloride) with a final concentration of $5 \mu \mathrm{g} \mathrm{mL} \mathrm{m}^{-1}$, and filtered on a $0.2-\mu \mathrm{m}$ pore diameter black Nuclepore polycarbonate membrane.

In certain cases, we took four DAPI-dyed photomicrographs from each sample with an ASA 800 Ektachrome film. The cellular volumes were calculated from length and width measurements of bacterial images photographed in randomly selected fields (see procedures in van Wambeke, 1988). Bacterial biomass was calculated from biovolume and total counts by applying a size-dependent conversion factor for organic carbon of $1.55 \times$

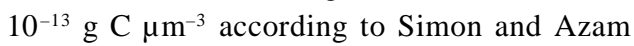
(1989) and Torréton (1991).

\section{RESULTS}

The results obtained from the extractions show that the content of ATP in the different microaerophilic bacterial growth levels varies mediciones de ATP fueron realizadas por la técnica luciferina-luciferasa utilizando un luminómetro 1250 LKB (Daumas, 1973; Burninson, 1975; Cavari, 1976).

Con el fin de calcular el carbón orgánico microaerofílico, y debido a que existe muy poca información sobre la cuantificación de la biomasa bacteriana microaerofílica en medios de cultivo, la concentración de ATP fue convertida en carbono celular usando un factor de conversión (C/ATP) de $250 \mu \mathrm{g}$ C/ $\mu \mathrm{g}$ ATP (Holm-Hansen, 1969; Karl, 1980; Romano, 1982), calculado para cultivos aerobios y anaerobios de fitoplancton y bacterioplancton, y un factor de $356 \mu \mathrm{g}$ C/ $\mu \mathrm{g}$ ATP, calculado en el transcurso de la presente investigación.

El conteo total de los efectivos bacterianos microaerofílicos se realizó por microscopía de epifluorescencia según Hobbie et al. (1977) y Porter y Feig (1980). La mayor dificultad en la utilización de esta técnica reside en la disociación de los agregados bacterianos y en la separación de las células de la matriz de agar que constituye el medio de cultivo.

Con el fin de separar las células bacterianas de la matriz de agar, $1 \mathrm{~mL}$ de la película con crecimiento bacteriano fue resuspendido en $9 \mathrm{~mL}$ de una solución al $0.002 \mathrm{M}$ de $\mathrm{Na}_{4} \mathrm{P}_{2} \mathrm{O}_{7}$ durante 20 minutos y después sonificada a $45 \mathrm{~W}$ ( $60 \%$ de eficiencia) durante 60 segundos con un procesador ultrasónico (Vibra Cell $600 \mathrm{~W}$, Bioblock Scientific) equipado con una sonda de $3 \mathrm{~mm}$; una alícuota de $250 \mathrm{~mL}$ de esta suspensión fue diluida en $10 \mathrm{~mL}$ de agua de mar esterilizada por filtración, conteniendo formaldehído al $0.25 \%$ (concentración final) y $0.05 \%$ de azida de sodio (Reimars y Smith, 1986). Se colorearon $2 \mathrm{~mL}$ del sobrenadante durante 10 minutos con DAPI (4',6-diamidina2-fenilindol dihidrocloruro) a una concentración final de $5 \mu \mathrm{g} \mathrm{mL}^{-1}$ y filtrados sobre una membrana de policarbonato Nuclepore negra de $0.2 \mu \mathrm{m}$ de diámetro de poro. 
according to the ring depth in the semi-solid agar column (fig. 1).

The counting of the total number of microaerophilic bacteria in every ring analyzed showed a range of $9.0 \times 10^{7}$ to $1.2 \times 10^{9}$ cells $\mathrm{mL}^{-1}$ (fig. 1). The regression analysis (fig. 2) shows a direct relation between the total number of microaerophilic bacteria and the ATP content $\left(R^{2}=0.95\right)$ in the rings.

The bacterial biomass calculated using the conversion factor of 250 varied from 0.6 to $45 \mu \mathrm{g} \mathrm{C} \mathrm{mL}^{-1}$.

The direct counting technique using a calculated mean cellular volume of $0.28 \mu \mathrm{m}^{3}$ and applying a size-dependent conversion factor for

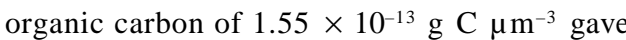
biomass values higher ( 4.0 to $56.0 \mu \mathrm{g} \mathrm{C} \mathrm{mL}^{-1}$ ) than those obtained by the ATP extraction technique.

In order to explain the differences in the values obtained with both techniques used in this investigation, we calculated the average concentration of ATP per microaerophilic bacterial cell $\left(1.22 \pm 0.43 \times 10^{-10} \mu \mathrm{g}\right.$ ATP cell $^{-1}$; $n=41$ ) cultivated in a nitrogen-free mineral medium, from the ATP concentrations and the total counts of bacteria obtained from each ring analyzed. This value coincides with those reported by Cavari (1976) and Geesey and Costerton (1979) for wild aquatic bacteria; nevertheless, it is ten times lower than the values reported by Hamilton and Holm-Hansen (1967) and Moriarty (1977) for cultivated cells.

Using this value of ATP contents and the concentration of carbon per microaerophilic cell $\left(4.34 \times 10^{-8} \mu \mathrm{g} \mathrm{C}\right.$ cell $\left.^{-1}\right)$, we calculated a C/ATP relation of $356 / 1$. The biomass values obtained using this conversion factor fluctuated between 1.28 and $53.40 \mu \mathrm{g} \mathrm{C} \mathrm{mL}^{-1}$, similar to those calculated using the cellular volume method and total counts (table 1), except for rings lower than $15 \mathrm{~mm}$ depth in the agar column which presented four times lower
En algunos casos, se tomaron cuatro fotomicrografías por muestra teñida con DAPI utilizando una película Ektachrome de 800 ASA. El volumen celular fue calculado a partir de las medidas de longitud y ancho de las imágenes bacterianas fotografiadas sobre campos seleccionados al azar (ver el procedimiento en van Wambeke, 1988). La biomasa bacteriana fue calculada a partir del biovolumen y del conteo total aplicando un factor de conversión para carbón orgánico, dependiente de la talla, de

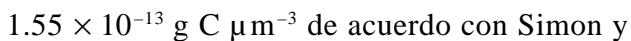
Azam (1989) y Torréton (1991).

\section{RESULTADOS}

Los resultados obtenidos de las extracciones muestran que el contenido de ATP en los diferentes niveles de crecimiento varía según la profundidad a la que éstos se encuentren dentro de la columna de agar semisólido (fig. 1).

El conteo del número total de bacterias microaerofílicas presentes en cada uno de los anillos analizados mostró un rango de $9.0 \times 10^{7}$ a $1.2 \times 10^{9}$ cel $\mathrm{mL}^{-1}$ (fig. 1). El análisis de regresión mostró la existencia de una relación directa entre el número total de efectivos microaerofílicos y el contenido de ATP $\left(R^{2}=\right.$ 0.95 ) en los anillos (fig. 2).

La biomasa bacteriana calculada utilizando el factor de conversión de 250 permitió obtener valores de 0.6 a $45.0 \mu \mathrm{g} \mathrm{C} \mathrm{mL}^{-1}$.

La técnica de conteo directo utilizando un volumen celular medio calculado de $0.28 \mu \mathrm{m}^{3}$ y aplicando un factor de conversión para carbón orgánico, dependiente de la talla, de

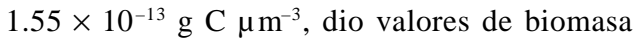
mayores (4.0 a $56.0 \mu \mathrm{g} \mathrm{C} \mathrm{mL}^{-1}$ ) que los obtenidos por la técnica de extracción de ATP.

Con el fin de explicar las diferencias en los valores de biomasa obtenidos por las dos técnicas utilizadas en esta investigación, se calculó la concentración media de ATP por 


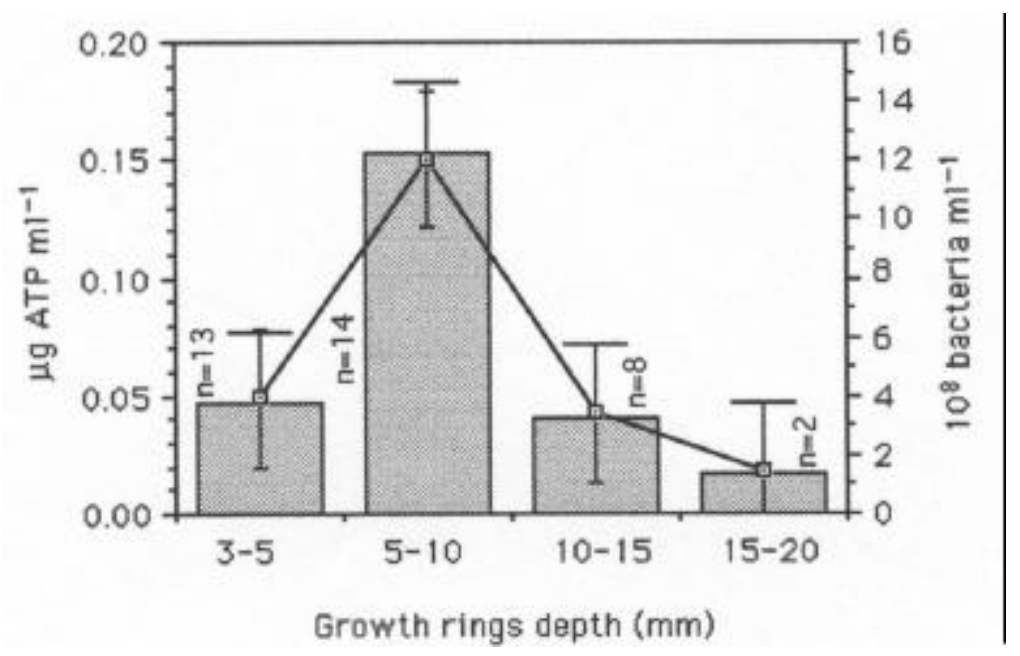

Figure 1. Average values of ATP concentration and of total bacteria in the microaerophilic growth rings. Depth $(\mathrm{mm})$ of the growth rings in the agar column, from the agar surface toward the deeper zones in the tube; $n=$ number of samples analyzed. ATP concentration (shaded area); number of total microaerophilic bacteria (continuous line).

Figura 1. Promedio de la concentración de ATP y del número total de células bacterianas en la zona de crecimiento microaerofílico. Profundidad $(\mathrm{mm})$ de la zona de crecimiento en la columna de agar, de la superficie del agar hacia las zonas más profundas del tubo; $n=$ número de anillos analizados. Concentración de ATP (área sombreada); conteo total de bacterias microaerofílicas (línea continua).

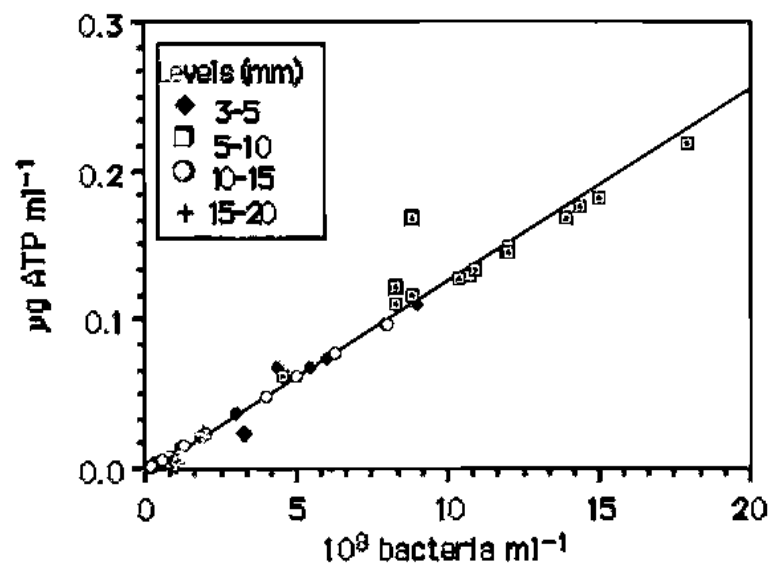

Figure 2. Linear correlation analysis between total number of bacteria versus ATP concentration in microaerophilic growth rings $\left(R^{2}=0.95\right) ; n=47$.

Figura 2. Análisis de correlación lineal entre el número total de bacterias y la concentración de ATP en las zonas de crecimiento microaerofílico $\left(R^{2}=0.95\right) ; n=47$. 
Ciencias Marinas, Vol. 26, No. 2, 2000

Table 1. Total bacterial number and microaerophilic bacterial biomass measurements based on (a) total

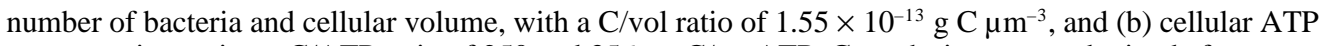
concentration, using a C/ATP ratio of 250 and $356 \mu \mathrm{g}$ C/ $\mu \mathrm{g}$ ATP. Growth rings were obtained after seven days incubation from different depths in the agar column.

Tabla 1. Efectivos bacterianos totales y biomasa bacteriana microaerofílica calculada a partir de (a) una

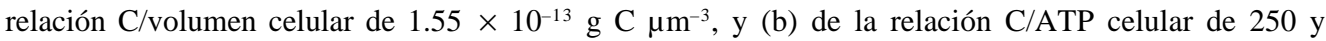
$356 \mu \mathrm{gC} / \mu \mathrm{g}$ ATP. Los anillos de crecimiento fueron obtenidos a diferentes profundidades de la columna de agar después de siete días de incubación.

\begin{tabular}{|c|c|c|c|c|}
\hline \multirow{2}{*}{$\begin{array}{l}\text { Depth } \\
\text { growth ring } \\
\quad(\mathrm{mm})\end{array}$} & \multirow[t]{2}{*}{$\begin{array}{l}\text { No. bacteria } \\
\left(10^{8} \mathrm{~mL}^{-1}\right)\end{array}$} & \multirow{2}{*}{$\begin{array}{l}\text { (a) Biomass } \\
\left(\mu \mathrm{g} \mathrm{mL}^{-1}\right) \\
\text { C/biovol }\end{array}$} & \multicolumn{2}{|c|}{$\begin{array}{l}\text { (b) Biomass } \\
\left(\mu \mathrm{g} \mathrm{C} \mathrm{mL}^{-1}\right)\end{array}$} \\
\hline & & & C/ATP (250/1) & C/ATP $(356 / 1)$ \\
\hline 3 & 1.3 & 6.0 & 3.80 & 5.34 \\
\hline 3 & 3.3 & 14.0 & 6.50 & 8.54 \\
\hline 3 & 1.9 & 8.0 & 5.45 & 7.48 \\
\hline 4 & 4.4 & 19.0 & 17.10 & 24.21 \\
\hline 5 & 12.0 & 52.0 & 37.38 & 53.40 \\
\hline 5 & 8.3 & 36.0 & 27.23 & 39.16 \\
\hline 5 & 8.8 & 38.0 & 42.35 & 60.52 \\
\hline 6 & 8.3 & 36.0 & 30.25 & 42.72 \\
\hline 7 & 5.0 & 22.0 & 15.03 & 21.72 \\
\hline 7 & 4.5 & 20.0 & 15.13 & 21.72 \\
\hline 15 & 0.9 & 4.0 & 0.91 & 1.28 \\
\hline
\end{tabular}

biomass values $\left(1.28 \mu \mathrm{g} \mathrm{C} \mathrm{mL}^{-1}\right)$ and low concentrations of oxygen $(<7 \mu \mathrm{M})$.

\section{DISCUSSION}

The fact that the ATP concentrations obtained from the microaerophilic growth rings were low may be related to the specific composition of the culture medium. This semi-solid nitrogen-free medium with limited concentrations in organic substrates is selective for diazotrophic bacteria able to use molecular nitrogen for their protein synthesis; this reaction is endergonical and consumes high quantities of ATP (Karl, 1980; Atlas, 1984). célula bacteriana microaerofílica $(1.22 \pm 0.43 \times$ $10^{-10} \mu \mathrm{g}$ ATP $\operatorname{cel}^{-1} ; n=41$ ) cultivada en un medio mineral carente de nitrógeno combinado, a partir de las concentraciones de ATP y el conteo total de efectivos bacterianos obtenidos en cada uno de los anillos analizados. Este valor coincide con los reportados por Cavari (1976) y Geesey y Costerton (1979) para bacterias acuáticas silvestres; sin embargo, es diez veces menor que los valores reportados por Hamilton y Holm-Hansen (1967) y Moriarty (1977) para células en cultivo.

Conociendo el contenido de ATP y la concentración de carbono por célula microaerofí-

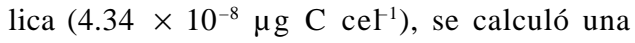


Ferrara-Guerrero and Bianchi: Microaerophilic bacterial biomass measurements

The low concentrations of ATP and bacterial cells in the aerobic zone between 3 and $5 \mathrm{~mm}$ depth and in the interface with the anaerobic zone of the agar column $(0.047 \pm$ $0.003 \mu \mathrm{g}$ ATP $\mathrm{mL}^{-1}$ and $0.018 \pm 0.008 \mu \mathrm{g} \mathrm{ATP}$ $\mathrm{mL}^{-1}$, respectively) may possibly be explained by the fact that microaerophilic bacteria show a low activity in the respiratory chain enzymes (superoxide dismutase, catalase and peroxidase) able to eliminate the oxygen's toxic radicals formed during their aerobic respiration (Stouthamer et al., 1979); this prevents them from growing in highly oxygenated zones. On the other hand, within the limits of the microaerophilic-anaerobic zone, the presence of facultative anaerobic bacteria with limited metabolic activity could explain these low concentrations owing to the fact that during their aerobic growth these microorganisms can elude from their respiratory metabolism oxidative phosphorilation (Stouthamer, 1976; Postgate, 1984) and then the energetic output per molecule of oxidated substrate will become less.

The intense microbial activity in the growth rings between 5 and $10 \mathrm{~mm}$ depth shows that the microaerophilic-diazotrophic bacterial population studied presented its highest metabolic activity in a range between 6 and $114 \mu \mathrm{M} \mathrm{O}_{2}$, as shown by the high counts of bacterial cells $\left(1.2 \pm 0.28 \times 10^{9}\right.$ cell $\left.\mathrm{mL}^{-1}\right)$ and $\operatorname{ATP}\left(0.15 \pm 0.029 \mu \mathrm{g} \mathrm{mL}^{-1}\right)$ concentrations registered in this zone.

The differences between these values and those calculated by the carbon/biovolume method may be explained by the presence of intact but inactive cells included within the counting, and an overevaluation of the cell volume from a photograph taken with an epifluorescence microscope, owing to a high fixation of the fluorochrome (Torréton, 1991).

In fact, the common problem in all biomass determination techniques lies in finding an relación C/ATP de 356/1. Los valores de biomasa obtenidos con este factor de conversión fluctuaron entre 1.28 y $53.40 \mu \mathrm{g} \mathrm{C} \mathrm{mL}^{-1}$, semejantes a los calculados por el método de volumen celular y conteo total (tabla 1), a excepción de los anillos localizados por debajo de $15 \mathrm{~mm}$ de profundidad en la columna de agar, los cuales presentaron valores de biomasa cuatro veces más bajos $\left(1.28 \mu \mathrm{g} \mathrm{C} \mathrm{mL}^{-1}\right)$, así como bajas concentraciones de oxígeno $(<7 \mu \mathrm{M})$.

\section{DISCUSIÓN}

El hecho de que las concentraciones de ATP obtenidas en los anillos de crecimiento microaerofílico fueron bajas puede estar relacionado con la composición específica del medio de cultivo. Este medio de cultivo, carente de nitrógeno combinado y con limitación en sustratos orgánicos, es selectivo para bacterias diazotrofas capaces de utilizar el nitrógeno molecular para su síntesis de proteínas; esta reacción es endergónica y consume grandes cantidades de ATP (Karl, 1980; Atlas, 1984).

Las bajas concentraciones de ATP y de células bacterianas registradas en la zona aerobia comprendida entre 3 y $5 \mathrm{~mm}$ de profundidad y en la frontera con la zona anaerobia de la columna de agar $\left(0.047 \pm 0.003 \mu \mathrm{g}\right.$ ATP $\mathrm{mL}^{-1}$ у $0.018 \pm 0.008 \mu \mathrm{g}$ ATP $\mathrm{mL}^{-1}$, respectivamente), pueden deberse a que las bacterias microaerofílicas presentan una baja actividad en las enzimas de la cadena respiratoria (superóxido dismutasa, catalasa y peroxidasa) capaces de eliminar los radicales tóxicos del oxígeno formados durante su respiración aerobia (Stouthamer et al., 1979); esto les impide crecer en zonas altamente oxigenadas. Por otra parte, en los límites de la zona microaerofílicaanaerobia, la presencia de bacterias anaerobias facultativas con una actividad metabólica 
Ciencias Marinas, Vol. 26, No. 2, 2000

appropriate conversion factor for every specific condition culture. Most of these factors were obtained from monospecific cultures and under optimum growth conditions. Thus, the variations in the ATP concentrations in different taxonomic groups are wide. Our results lead us to believe that the conversion factor C/ATP of 356 is more appropriate than that of 250 proposed by Holm-Hansen (1969) for measuring the microaerophilic bacterial biomass exposed to the stress of a semi-solid nitrogen-free medium with low concentrations of organic substrates.

Nevertheless, it is difficult to determine which of the two methods used during this investigation (carbon/biovolume or carbon/ ATP ratio) gave the most exact organotrophicmicroaerophilic-diazotrophic bacterial biomass values. It is clear that the highest values were obtained by the direct/biovolume counting method, but we must make sure this is the living bacterial biomass. This fact limits the usefulness of the carbon/biovolume ratio as a method of estimating the microaerophilic bacterial biomass and could be the main reason for the discrepancy in the results obtained with the two methods.

\section{ACKNOWLEDGEMENTS}

We thank Richard H. Day for his valuable comments and reviews of the manuscript and Raoul Daumas for assistance in the ATP analysis.

\section{REFERENCES}

Anderson, F.Ø. and Helder, W. (1987). Comparison of oxygen microgradients, oxygen flux rates and electron transport system activity in coastal marine sediments. Mar. Ecol. Prog. Ser., 37: 259-264.

Atlas, R.M. (1984). Microbiology. Fundamentals and Applications. McMillan, New York, 818 pp. reducida podría explicar estas bajas concentraciones, ya que durante su crecimiento aerobio estos microorganismos pueden eludir de su metabolismo respiratorio la fosforilación oxidativa (Stouthamer, 1976; Postgate, 1984) y, por consiguiente, el rendimiento energético por molécula de sustrato oxidado será menor.

La intensa actividad microbiana registrada en los anillos de crecimiento localizados entre 5 y $10 \mathrm{~mm}$ de profundidad indica que la población bacteriana microaerofílica-diazotrofa estudiada presentó su máxima actividad metabólica en un rango de 6 a $114 \mu \mathrm{M} \mathrm{O}_{2}$ de oxígeno disuelto, como lo muestran las altas concentraciones de células bacterianas (1.2 \pm $0.28 \times 10^{9}$ cel $\left.\mathrm{mL}^{-1}\right)$ y de ATP $(0.15 \pm 0.029 \mu \mathrm{g}$ $\left.\mathrm{mL}^{-1}\right)$ registradas en esta zona.

Las diferencias existentes entre estos valores y los cálculos por el método carbono/ biovolumen pudieron deberse a la presencia de células intactas pero inactivas englobadas en el conteo y a la sobrestimación del volumen celular a partir de fotografías obtenidas por microscopía de epifluorescencia, debido a una fuerte fijación del fluorocromo (Torréton, 1991).

Por otra parte, el problema común en todas las técnicas de evaluación de biomasa reside en encontrar un factor de conversión adecuado. La mayor parte de estos factores han sido obtenidos a partir de cultivos monoespecíficos y bajo condiciones óptimas de crecimiento. Por tanto, existe una amplia gama de variaciones en la concentración de ATP en los diferentes grupos taxonómicos. Los resultados obtenidos en esta investigación permiten pensar que el factor de conversión C/ATP de 356 es más adecuado que el de 250 propuesto por Holm-Hansen (1969) para evaluar la biomasa bacteriana microaerofílica expuesta al estrés de un medio de cultivo semisólido carente de nitrógeno combinado y bajas concentraciones de sustratos orgánicos. 
Ferrara-Guerrero and Bianchi: Microaerophilic bacterial biomass measurements

Bowdre, J.H., Krieg, N.R., Hoffman, P.S. and Smibert, R.M. (1976). Stimulatory effect of dihydroxyphenyl compound on the aerotolerance of Spirillum volutans and Campylobacter fetus subspecies jejuni. Appl. Environ. Microbiol., 31: 127-133.

Burnison, K.B. (1975). Microbial ATP studies. Verh. Intemat. Verein. Limnol., 19: 286-290.

Cavari, B. (1976). ATP in Lake Kinneret: indicator of microbial biomass or of phosphorus deficiency. Limnol. Oceanogr., 21: 231-236.

Daumas, R.A. (1973). Evaluation de la teneur en Adenosine Triphosphate des organismes marins: possibilités actuelles et limites de la méthode. Téthys, 5: 71-80.

Daumas, R.A. (1989). Les bactéries de la couche superficielle du sédiment. In: M. Bianchi, D. Marty, J.C. Bertrand, P. Caumette and M. Gauthier (eds.), Micro-organismes dans les écosystèmes océaniques. Masson, Paris, pp. 201-218.

Ferrara-Guerrero, M.J. and Bianchi, A. (1989). Comparison of culture methods for enumeration of microaerophilic bacteria in marine sediments. Res. Microbiol. Inst. Pasteur, 140: 225-261.

Ferrara-Guerrero, M.J. and Bianchi, A. (1990). Distribution of microaerophilic bacteria through the oxic-anoxic transition zone of lagoon sediments. Hydrobiologia, 207: 147-152.

Ferrara-Guerrero, M.J., Marty, D. and Bianchi, A. (1993). Isolation and enumeration of anaerobic and microaerophilic bacteria in aquatic habitats. In: P.F. Kemp, B.F. Sherr, E.B. Sherr and J.J. Cole (eds.), Current Methods in Aquatic Microbial Ecology. Lewis Publishers, Boca Raton, pp. 9-19.

Focht, D.D. (1992). Diffusional constraints on microbial processes in soil. Soil Sci., 154: 300-307.

Geesey, G.G. and Costerton, J.W. (1979). Bacterial biomass determination in a silt-laden river: Comparison of direct count epifluorescence microscopy and extractable Adenosine Triphosphate techniques. In: J.W. Costerton and R.R. Colwell (eds.), Native Aquatic Bacteria: Enumeration, Activity, and Ecology. ASTM Technical Publications, Philadelphia, pp. 117-127.
No obstante, es difícil determinar cuál de los dos métodos utilizados (relación carbono/ biovolumen o carbono/ATP) durante esta investigación dio los valores más exactos de biomasa bacteriana organotrofa-microaerofílica-diazotrofa. Está claro que los valores más elevados fueron obtenidos por el método de conteo directo/biovolumen, pero falta saber si ésta representa la biomasa bacteriana viva. Este hecho limita la utilidad de la tasa carbono/ biovolumen como un método de evaluación de la biomasa bacteriana microaerofílica y podría ser la razón principal de la discrepancia en los resultados obtenidos con los dos métodos utilizados.

\section{AGRADECIMIENTOS}

Agradecemos a Richard H. Day sus valiosos comentarios y revisiones hechas al manuscrito y a Raoul Daumas por su asistencia en el análisis del ATP.

Traducido al español por los autores.

Hamilton, R.D. and Holm-Hansen, O. (1967). Adenosine Triphosphate content of marine bacteria. Limnol. Oceanogr., 12: 319-324.

Hobbie, J.E., Daley, R.J. and Jasper, S. (1977). Use of Nuclepore filters for counting bacteria by fluorescence microscopy. Appl. Environ. Microbiol., 33: 1225-1228.

Holm-Hansen, O. and Booth, C.R. (1966). The measurement of Adenosine Triphosphate in the ocean and its ecological significance. Limnol. Oceanogr., 11: 510-519.

Holm-Hansen, O. (1969). Determination of microbial biomass in ocean profiles. Limnol. Oceanogr., 14: 740-747.

Holm-Hansen, O. (1970). ATP levels in algal cells as influenced by environmental conditions. Plant Cell Physiol., 11: 689-700.

Jones, J.G. (1982). Activities of aerobic and anaerobic bacteria in lake sediments and their effect on the water column. In: D.B. Nedwell and 
Ciencias Marinas, Vol. 26, No. 2, 2000

C.M. Brown (eds.), Sediment Microbiology. Academic Press, London, pp. 107-145.

Jones, J.G. (1987). Diversity in freshwater microbiology. In: M. Fletcher, T.R.G. Gray and J.G. Jones (eds.), Ecology of Microbial Communities. Cambridge Univ. Press, Cambridge, pp. 235-259.

Karl, D.M. (1980). Cellular nucleotide measurements and applications in microbial ecology. Microbiol. Rev., 44: 739-796.

Karl, D.M. (1982). Microbial transformations of organic matter at oceanic interfaces: A review and prospectus. EOS, 63: 138-140.

Kikuchi, H.E. and Suzuki, T. (1986). Quantitative method for measurement of aerotolerance of bacteria and applications to oral indigenous anaerobes. Appl. Environ. Microbiol., 52: 971-973.

Laborde, P. (1972). L’Adénosine Triphosphate des micro-organismes marins planctoniques. Rapport avec la biomasse et la productivité primaire. Ph.D. thesis, Université d'AixMarseille II, France, 108 pp.

McDonough, R.J., Sanders, R.W., Porter, K.G. and Kirchman, D.L. (1986). Depth distribution of bacterial production in a stratified lake with anoxic hypolimnion. Appl. Environ. Microbiol., 52: 992-1000.

MacFarlane, G.T., Russ, M.A., Keith, S.M. and Herbert, R.A. (1984). Simulation of microbial processes in estuarine sediments using gelstabilized systems. J. Gen. Microbiol., 130: 2927-2933.

Millero, F.J. and Sohn, M.L. (1992). Chemical Oceanography. CRC Press, Boca Ratón, 531 pp.

Moriarty, D.J.W. (1977). Improved method using muramic acid to estimate biomass of bacteria in sediments. Ecologia, 26: 317-323.

Nielsen, L.P., Christensen, P.B., Revsbech, N.P. and Sørensen, J. (1990). Dinitrification and oxygen respiration in biofilms studied with a microsensor for nitrous oxide and oxygen. Microb. Ecol., 19: 63-72.

Porter, K.G. and Feig, Y.S. (1980). The use of DAPI for identifying and counting aquatic microflora. Limnol. Oceanogr., 25: 943-948.

Postgate, J.R. (1984). The Sulphate-reducing Bacteria. 2nd ed. Cambridge Univ. Press, Cambridge, 208 pp.
Reddy, K.R., Patrick, W.H. and Lindau, C.W. (1989). Nitrification-denitrification at the plant root-sediment interface in wetlands. Limnol. Oceanogr., 34: 1004-1013.

Reimers, C.E. and Smith, L. (1986). Reconciling measured and predicted fluxes of oxygen across the deep sea sediment-water interface. Limnol. Oceanogr., 31: 305-318.

Revsbech, N.P. and Jørgensen, B.B. (1986). Microelectrodes: Their use in microbial ecology. Adv. Microb. Ecol., 9: 293-352.

Romano, J.C. (1982). Les nucléotides adényliques (ATP, ADP, AMP) dans le milieu marin (matière organique particulaire des eaux et sédiments superficiels). Applications à l'étude de la microbiomasse. Ph.D. thesis, Univ. AixMarseille II, France, 222 pp.

Simon, M. and Azam, F. (1989). Protein content and protein synthesis rates of plankton bacteria. Mar. Ecol. Prog. Ser., 51: 201-213.

Skopp, J., Jawson, M.D. and Doran, J.W. (1990). Steady-state aerobic microbial activity as a function of soil water content. J. Soil Sci. Soc. Am., 54: 1619-1625.

Smith, K.A. and Arah, J.R.M. (1986). Anaerobic microenvironments and the occurrence of anaerobic bacteria. In: V. Jensen, A. Kjøller and L.H. Sørensen (eds.), Microbial Communities in Soil. Elsevier, London, pp. 247-261.

Stouthamer, A.H. (1976). Biochemistry and genetics of nitrate reductase in bacteria. In: A.H. Rose and D.W. Tempest (eds.), Advances in Microbial Physiology. Academic Press, New York, pp. 315-351.

Stouthamer, A.H., De Vries, W. and Niekus, H.G.D. (1979). Microaerophily. Antonie van Leeuwenhoek, 45: 5-12.

Torréton, J.P. (1991). Importance des bactéries hétérotrophes aérobies dans une lagune eutrophe tropicale (Lagune Ebrié, Côte d'Ivoire). Biomasse, production, exportations. Ph.D. thesis, Univ. Aix-Marseille II, France, 246 pp.

Torréton, J.P., Guiral, D. and Arfi, A. (1989). Bacterioplankton biomass and production during destratification in a monomitic eutrophic bay ofa tropical lagoon. Mar. Ecol. Prog. Ser., 57: 53-67.

Van Wambeke, F. (1988). Numération et taille des bactéries planctoniques au moyen de l'analyse 
Ferrara-Guerrero and Bianchi: Microaerophilic bacterial biomass measurements

d'images couplée à l'épifluorescence. Ann. Inst. Pasteur/Microbiol, 139: 261-272.

Wimpenny, J.W.T. and Waters, P. (1984). Growth of micro-organisms in gel-stabilized twodimensional diffusion gradient systems. J. Gen. Microbiol., 130: 2921-2926.

Wimpenny, J.W.T., Lovitt, R.W. and Coombs, J.P. (1983). Laboratory model for the investigation of spatially and temporally organized microbial ecosystems. In: J.H. Slater, R. Whittenbury and J.W.T. Wimpenny (eds.), Microbes in their Natural Environments. 34th Symposium of the Society for General Microbiology, University of Warwick. Cambridge Univ. Press, pp. 67-117.

Wynn-Williams, D.D. (1992). Ecological aspects of Antarctic microbiology. Adv. Microb. Ecol., 11: 71-146. 